\title{
Supply Chain Management and MSMEs Growth in Developing Countries: A Focus on North Central Region of Nigeria
}

\author{
Emmanuel Okokondem Okon ${ }^{1}$ \\ ${ }^{1}$ Department of Economics, Kogi State University, Anyigba, Kogi State, Nigeria \\ Correspondence: Department of Economics, Kogi State University, Anyigba, Kogi State, Nigeria. E-mail: \\ tonydom57@yahoo.com.Tel: +2348023275716
}

Received: January 1, 2018

Accepted: January 4, 2018

Online Published: January 17, 2018

\begin{abstract}
Today's business environment for Micro, Small, and Medium Enterprises (MSMEs) as well as large, global companies is more fluid and complex than ever before. Companies are adapting their supply chains to respond to increasingly competitive market conditions and to deliver higher revenue and greater value to their shareholders and customers. The study employed retrospective design. Respondents were selected using purposive sampling to arrive at the desired sample of the owners of Micro, Small, and Medium Enterprises in selected states of the north-central Nigeria. The 5-point Likert scale was employed to allow for precise responses on some issues raised regarding their supply chain management. Given the data gathered and generally ranking the totality of the Micro, Small, and Medium Enterprises in terms of least performance based on the indicators used, the result shows that the Micro, Small, and Medium Enterprises performed least on Total Delivered Cost followed by Operating Costs, Performance to Plan, Inventory, Supply Variability, Demand Variability, and Customer Service. In order to succeed, Micro, Small, and Medium Enterprises in Nigeria, particularly in the north-central states need to be able to increase inventory velocity, achieve the shortest possible cycle times, continually improve their supplier performance and drive their sales and market share.
\end{abstract}

Keywords: Supply Chain Management, Key Performance Indicators, MSMEs, Growth, North Central, Nigeria.

\section{Introduction}

Recently there has been growing assertion that the earlier emphasis on large-scale enterprises in developing countries had minimum success in generating employment, economic growth and alleviating poverty (Rosenzweig, 1988; Brown et al., 1990). For this reason, many began to believe that providing a suitable macroeconomic environment that enhances the self-development of small and medium-sized enterprises is an effective way of stimulating growth and equity.

Business Efficiency is a situation in which an organization maximizes benefit and profit while minimizing effort and expenditure (Cummins, 2003). A number of empirical studies have been conducted on SMEs efficiency in both developing and developed countries(Alvarez and Crespi, 2001; Ajibefun and Daramola, 2003; Lee and Harvie; 2010). The lack of efficiency affects all businesses whether small or big. Inefficiencies in larger businesses 
may go unnoticed due to the availability of excess resources. Smaller businesses may not survive or fail to grow due to the inefficiencies regardless of the nature of the business.

When business people talk about supplier management, they refer to the systems, technology, and procedures that connect a supplier to a customer. An efficient and performing supply chain helps a business save money, thanks to faster client deliveries, shorter factory processing times, and better inventory management. This, in turns, reduces spoilage and decay (Meeken, 2013).

Many developing countries have tried to implement policies that could enhance productivity and efficiency in SMEs; however, these policies have not had any significant impact on the performance of the SMEs. In Nigeria, Micro, Small and Medium Enterprises (SMEs) have not performed creditably well and hence have not played the expected vital and vibrant role in the economic growth and development of the country. This situation has been of great concern to the government, citizenry, operators, practitioners and the organized private sector groups(Onugu, 2005).

Located in the continent of Africa, Nigeria covers 910,768 square kilometers of land and 13,000 square kilometers of water, making it the 32nd largest nation in the world with a total area of 923,768 square kilometers(Worldatlas, n.d.). The latitudinal and longitudinal extent of the country is $4^{\circ}$ to $14^{\circ} \mathrm{N}$ and $2^{\circ}$ to $15^{\circ} \mathrm{E}$ respectively (Maps of World, n.d.). Its coastal boundary is delimited by the Gulf of Guinea in the south and the land boundary is shared by Cameroon and Chad in the east, Niger in the north and Benin in the west.

There are 36 States in Nigeria, bound together by a federal agreement, plus the Federal Capital Territory (FCT), which is not a state but a territory under the direct control of the Federal Government (Wikipedia, n.d.).Abuja is Nigeria's capital city and Lagos is its largest city. Nigeria covers a total area of 923,768 sq. km making it the thirty second largest countries in the world. It has a small coastline of $853 \mathrm{~km}$ in comparison to its total land boundary of 4047 km (Maps of World, n.d.).

Economically, Nigeria has one of the strongest economies in Africa, in 2014 it became the largest economy in Africa. The presence of the oil reserves in the country has contributed to its growing economy.This paper investigates MSMEs' efficiency in Nigeria by using crucial Key Performance Indicators that can be assessed to check the health of their supply chain. This is because supply chain management is an integral part of most businesses and is essential to company success and customer satisfaction. The outcome of this research is intended to optimizing MSMEs operations to maximize both speed and efficiency in the current competitive business environment and global marketplace where customers are more demanding to have better and cheaper products, higher service levels, more product varieties and faster delivery (Chow et al., 2008; Ketchen et al., 2008).

\section{Supply Chain Concepts}

Before an organization tries to focus on supply chain management, its leaders must determine what the supply chain encompasses. Just as you can't manage what you don't measure, you can't plan and execute what you haven't clearly defined. Hence, it is important to articulate the overall purpose, scope, and components of a supply chain. Following are useful supply chain definitions that highlight critical aspects of a supply chain: a) The material and informational interchanges in the logistical process, stretching from acquisition of raw materials to delivery of finished products to the end user. All vendors, service providers, and customers are links in the supply chain (Council of Supply Chain Management Professionals, 2010); b) The network of organizations that are involved, through upstream and downstream linkages, in the different processes and activities that produce value in the form of products and services delivered to the ultimate consumer(Christopher, 1992); c)A series of integrated enterprises that must share information and coordinate physical execution to ensure a smooth, integrated flow of goods, services, information, and cash through the pipeline (Coyle, Langley, Novak, and Gibson, 2013). 
One important feature of these definitions is the concept of an integrated network or system. A simplistic depiction of a supply chain, as featured in Figure 1, suggests that a supply chain is linear with organizations linked only to their immediate upstream suppliers and downstream customers. It also focuses on only one-way material flow, which fails to consider vital information, and financial flows, as well as reverse material flows. Such misconceptions oversimplify reality and fail to reveal the dynamic nature of a supply chain network.

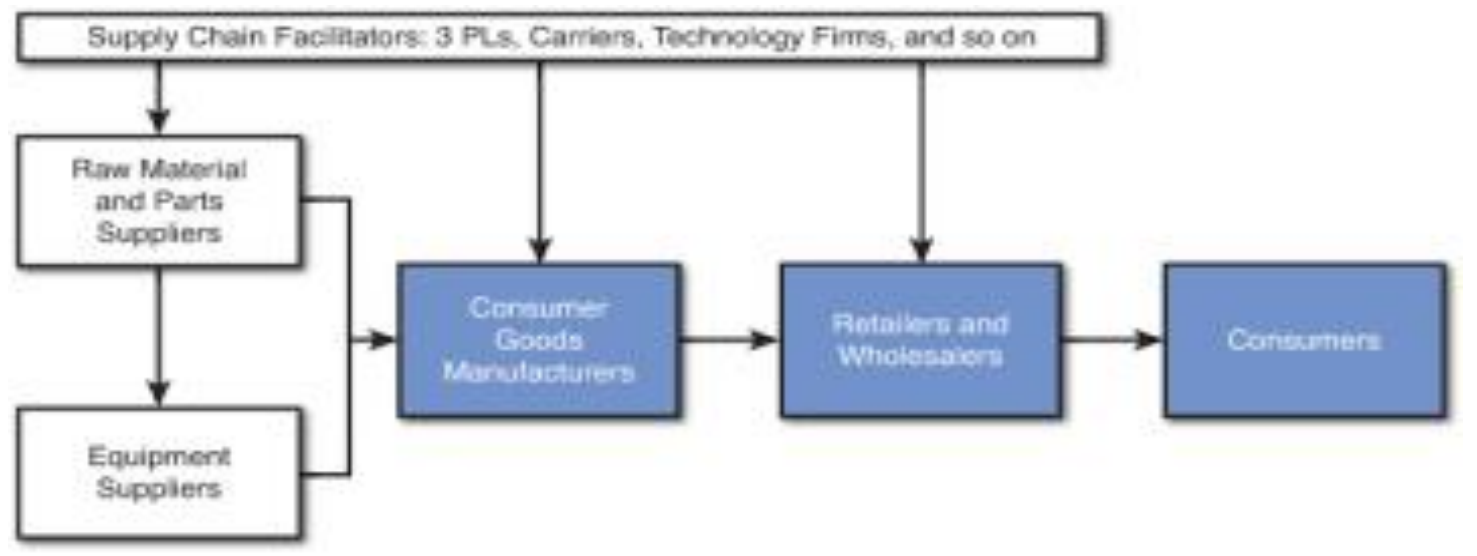

Figure 1: Linear representation of a supply line

Source: (CSCMP, 2014).

In truth, supply chains require a multiplicity of relationships and numerous paths through which products and information travel. This is better reflected in the conceptual diagram of a supply chain in Figure 2, in which the supply chain is a web or network of participants and resources. To gain maximum benefit from the supply chain, a company must dynamically draw upon its available internal capabilities and the external resources of its supply chain network to fulfill customer requirements. This network of organizations, their facilities, and transportation linkages facilitate the procurement of materials, transformation of materials into desired products, and distribution of the products to customers.

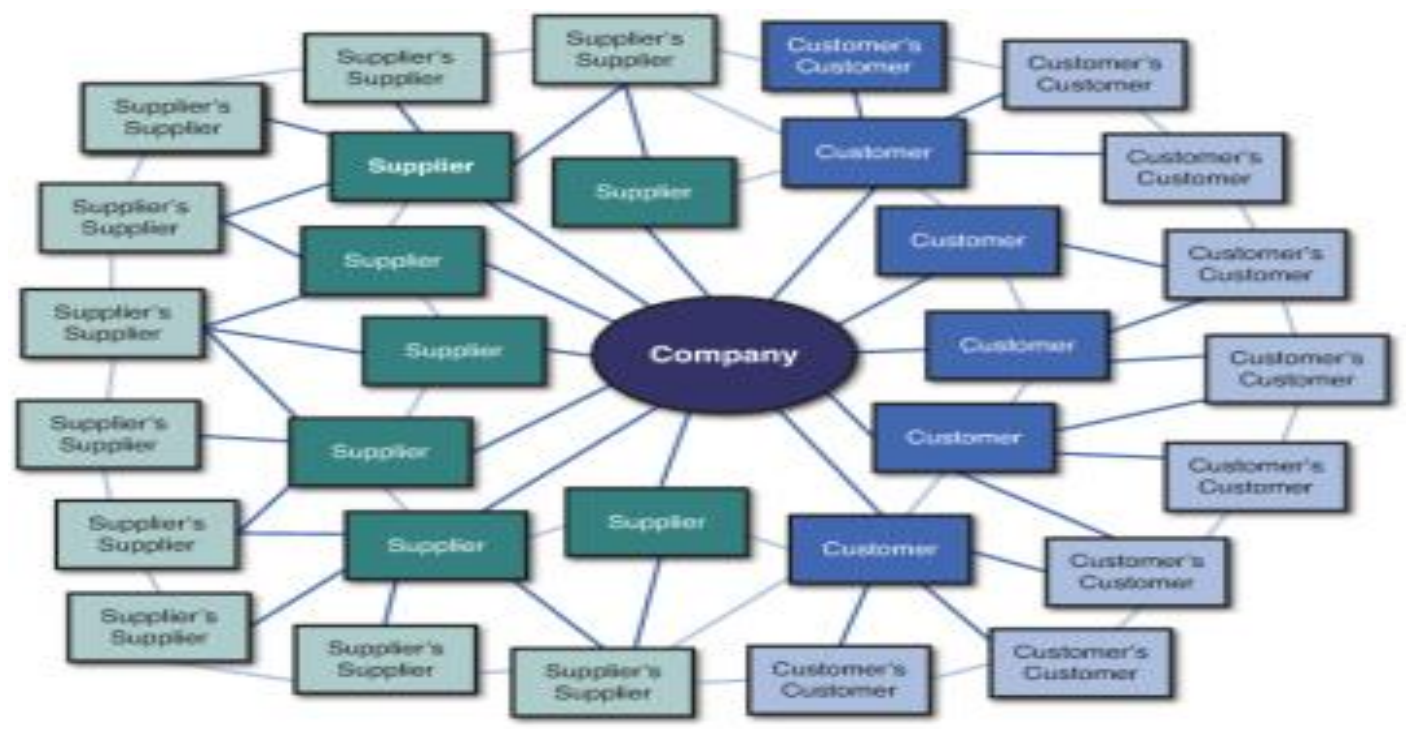

Figure 2: Network representation of a supply chain

Source: (CSCMP, 2014).

Simple representations aside, it is critical to understand that no two supply chains are exactly alike. An organization's supply chain structure and relationships will be influenced by its industry, geographic scope of 
activity, supply base, product variety, fulfillment methods, and demand patterns. Consider, for example, a multinational manufacturer and a local farm-to-table restaurant. Both organizations would benefit from strong and stable supply chains. However, the manufacturer's network is at greater risk of disruption and must integrate geographically diverse suppliers with multiple selling channels (CSCMP, 2014).

\section{Literature Review of Supply Chain Performance}

Li et al.(2006) define supply chain management practices as the set of activities undertaken by an organization to promote effective management of its supply chain and propose five dimensions of supply chain management practices: strategic supplier partnership, customer relationship, level of information sharing, quality of information sharing, and postponement. These practices influence positively the financial performance, the market performance and create a competitive advantage for the company in terms of price, quality, reliability, product innovation and time to market. Chowa et al. (2008) add others practices like communication, integration and customer service management, supply chain concerns, information sharing and specify that even if these practices are different geographically, they influence always positively the total performance of the chain.

Klein (2007) examines supply chain management relationships between service providers and clients and focuses on the impacts of the provider's information exchange behavior and both parties' level of trust. Trust has been established as a core component of persistent business partnerships and strategic alliances (Ganesan, 1994; Gulati, 1995). Trust influences cooperation and teamwork within organizations characterized as mutually beneficial initiatives. The relationship between service providers and clients is also based on the level of client customization of integrated supply chain functions through outsource service providers' e-business applications and solutions.

Fynes, B., Voss, C., Seán, d. B., (2005) study the nature of supply chain relationships with the aim of improving customer satisfaction. The authors define the supply chain relationship quality as the degree to which both parties in a relationship are engaged in an active, long-term working relationship, and using indicators of communication, trust, adaptation, commitment, interdependence, and co-operation. The mutual interest of the works presented above is that they try to improve the supply chain performance while following several strategies or models. The use of information technologies, information exchange, and sharing, inter-organizational communication, trust, cooperation and intra- and inter-organizational collaboration form essential factors of supply chain performance. However, a company must be able to clearly define its requirements in performance in order to identify which are the best practices meeting these needs.

\section{Supply Chain Management in MSMEs}

Even though supply chain is defined in different ways in different kinds of literature, most definitions are for large-scale industries and are built on the same concept. Defining supply chain in MSMEs might be a little bit difficult because most MSMEs lack organized structure and are mostly managed by their owners. However, quite a number of literatures has been written on the supply chain of SMEs. Most literature have addressed the fact that the supply chain of MSMEs is controlled and determined mostly by their big customers instead of themselves (Trungand Belihu,2010).

The MSMEs view of supply chain management seems to be the exertion of power by customers and is consequently seen by MSMEs as a one-way process. Similarly, MSMEs do not employ supply chain management rather they are managed at arm's length by larger customers (Quayle, 2003). Some also have defined the supply chain of MSMEs as supply chain in MSMEs is a set of business activities including purchase from open/spot market, manufacturing or processing of subcomponents/subassembly within the plant and delivery to large enterprises using hired transportation to enhance value of end product and in"turn to ensure long"term regular purchase orders (Thakkar et al., 2008). 


\section{SMEs in Nigeria and their Challenges}

Nigeria's large population portends a huge market for MSME products and services. Over the past five years, MSMEs' contribution to Nigeria's GDP has grown steadily at a compound annual growth rate of $3.51 \%$ to $51 \%$ in 2014. Agusto and Co (n.d.) estimate that MSMEs will account for around 56\% of GDP by 2016, largely due to the growth in wholesale and retail trade MSMEs.Small and Medium Enterprises(SMEs) as defined by the National Council of Industries are business enterprises whose total cost excluding land is not more than two million naira $(\mathrm{N} 2,000,000)$ only (Connect Nigeria, n.d.). The Federal Ministry of Commerce and Industry defines SMEs as firms with a total investment (excluding the cost of land but including capital) of up to N750,000 and paid employment of up to fifty(50) persons (Connect Nigeria, n.d.).

In Nigeria, SMEs are distributed by clusters within regions (see Figure 3 for selected regional andsectoraldistribution of SME clusters in Nigeria).Despite an understanding of the importance of MSMEs in the country, there is a dearth of information about their number, people they employed and the sector they operate in with Nigeria. The Micro, Small and Medium Enterprises are globally acknowledged as the oil required lubricating the engine of socio-economic transformation of any nation. The MSME sector is strategically positioned to absorb up to $80 \%$ of jobs, improve per capita income, increase value addition to raw materials supply, improve exports earnings and step up capacity utilization in key industries.

The Small and Medium Enterprises Development Agency of Nigeria(SMEDAN) was established in 2003, to facilitate the promotion and development of a structured and efficient Micro, Small and Medium Enterprises (MSMEs) sector that will enhance sustainable economic development in Nigeria.

In the year 2010, SMEDAN and NBS conducted a survey to combat the challenges associated with building a credible and reliable MSME database required to strategically reposition the sector. The bureau revealed its survey result: there were 17.28 million MSMEs in Nigeria employing 32. 41 million people (Connect Nigeria, n.d.). A breakdown shows that:Micro enterprises constituted 17,261,753 or $99.87 \%$;Small enterprises accounted for 21, 264 or $0.12 \%$; Medium scale enterprises were 1, 654 in number or $0.01 \%$ (Kale,2015).

According to a recent survey and findings by Economist Insight, to support SME productivity, Nigeria's government must stabilize macroeconomic policy and install a more transparent tax and customs system. In its survey, it also buttresses the need to support greater productivity gains, the importance of now turning to simplifying the tax system, reducing import barriers, stabilizing macroeconomic policy and building a more transparent customs system.

Most SMEs in Nigeria die within their first five years of existence, a smaller percentage goes into extinction between the sixth and tenth year, while only about five to ten percent survive, thrive and grow to maturity. SMEs encounter issues such as insufficient capital, irregular power supply, infrastructural inadequacies (water, roads, etc.), lack of focus, inadequate market research, over-concentration on one or two markets for finished products, lack of succession plan, inexperience, lack of proper book keeping, lack of proper records or lack of any records at all, inability to separate business and family or personal finances, lack of business strategy, inability to distinguish between revenue and profit, inability to procure the right plant and machinery, inability to engage or employ the right caliber of staff, and cut-throat competition. 


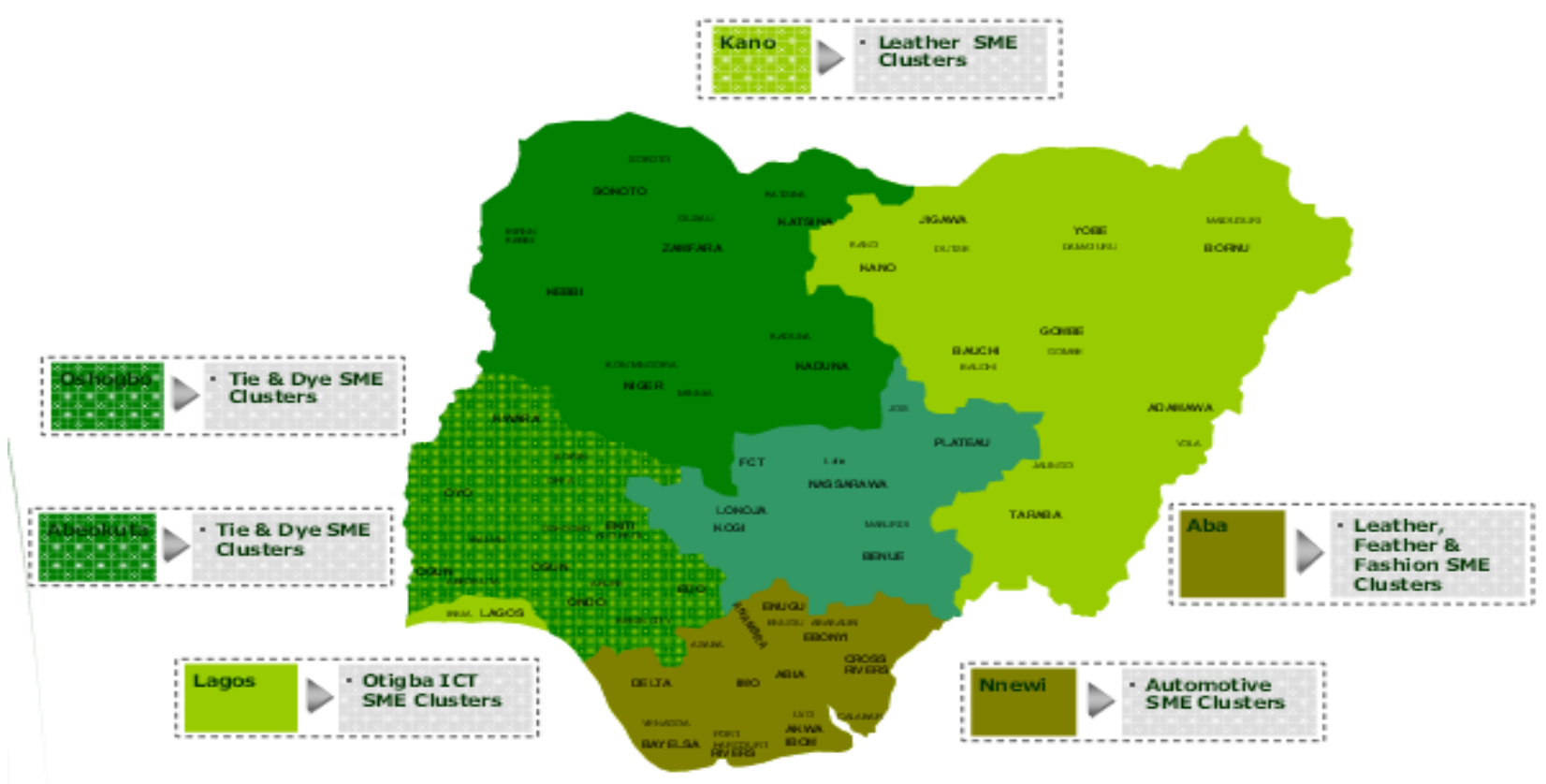

Figure 3: Selected Regional andSectoral Distribution of SME Clusters in Nigeria

Source: Oyelaran-Oyeyinka (n.d.).

\section{Area of Study: North Central Nigeria}

North Central Nigeria consists of the seven states(Plateau, Niger, Nasarawa, Kwara, Kogi, Benue, and FCT Abuja) situated geographically in the middle belt region of the country, spanning from the west, around the confluence of the River Niger and the River Benue (see Figure 4). The region itself is rich in natural land features and boasts some of Nigeria's most exciting scenery. The region is also home to many historical and colonial relics (MydNigeria ,n.d.).

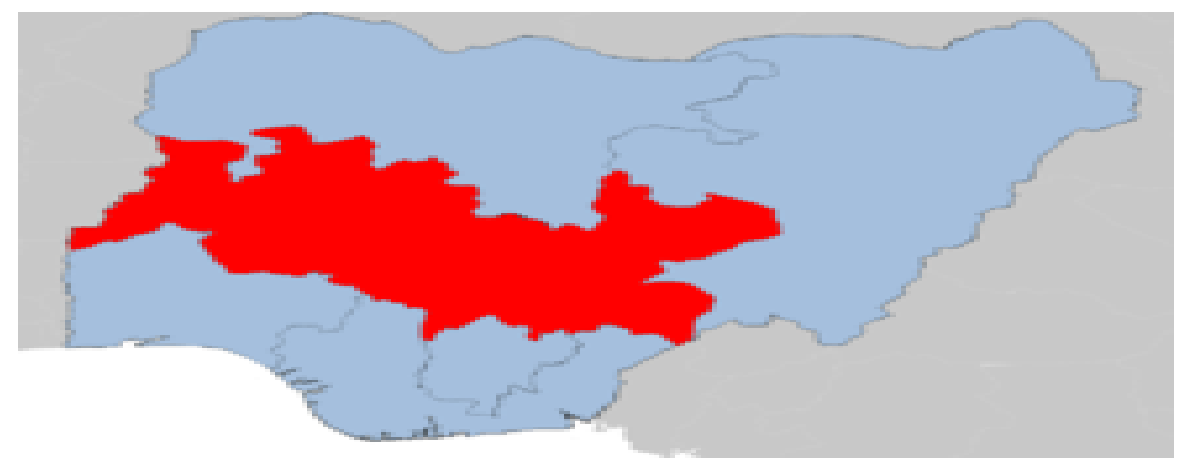

Figure 4: Map of Nigeria showing the North Central States

Source:eRepublik Wiki (n.d.).

\section{Method of Study}

The study employed retrospective design. Respondents were selected using purposive sampling to arrive at the desired sample of the owners of MSMEs in selected states of north central Nigeria. A total of sixteen (16) MSMEs were selected. Along with interactive session and in-depth interviews were held with each of the selected MSMEs over a period of two months. Data were collected based on the information gathered. This was done by the researcher later filling structured questionnaires(in absentia) to indicate the responses of the respondents.The 5-point Likert scale was employed to allow for precise responses. The devised Likert questions were to show 
participants rating of their supply chain management on seven aspects: Total Delivered Cost, Customer Service, Supply Variability, Demand Variability, Operating Costs, Performance to Plan, and Inventory. The participants rating was to indicate whether or not they were very unsatisfied, unsatisfied, neither satisfied nor dissatisfied, satisfied, or very satisfied with each issue under supply chain management that feedback was to be collected on. The responses on the key performance indicators of the supply chain were qualitative, however, this Likert scales ascribed quantitative value to qualitative data, to make it amenable to statistical analysis such as frequency count, average, and percentages. Though, the structured questionnaire reflected some key performance indicators (KPIs) which are critical in evaluating efficiency of the MSMEs' supply chain. It should be noted that a whole catalog of KPI's can be used to measure performance, but the main purpose of using the selected few is to shine a light on the difference between what is planned by a firm and what is really executed in its supply chain management. Making best use of these indicators helps a firm to improve on and correct weaknesses identified in the supply chain.

\section{Presentation of Data and Discussion of Result}

As reflected in Figure 5, a total of sixteen (16) MSMESs were selected from the north-central states of Nigeria: Microenterprises constituted 2or 12\%; Small enterprises accounted for 10 or $63 \%$; Medium scale enterprises were 4 in number or $25 \%$.

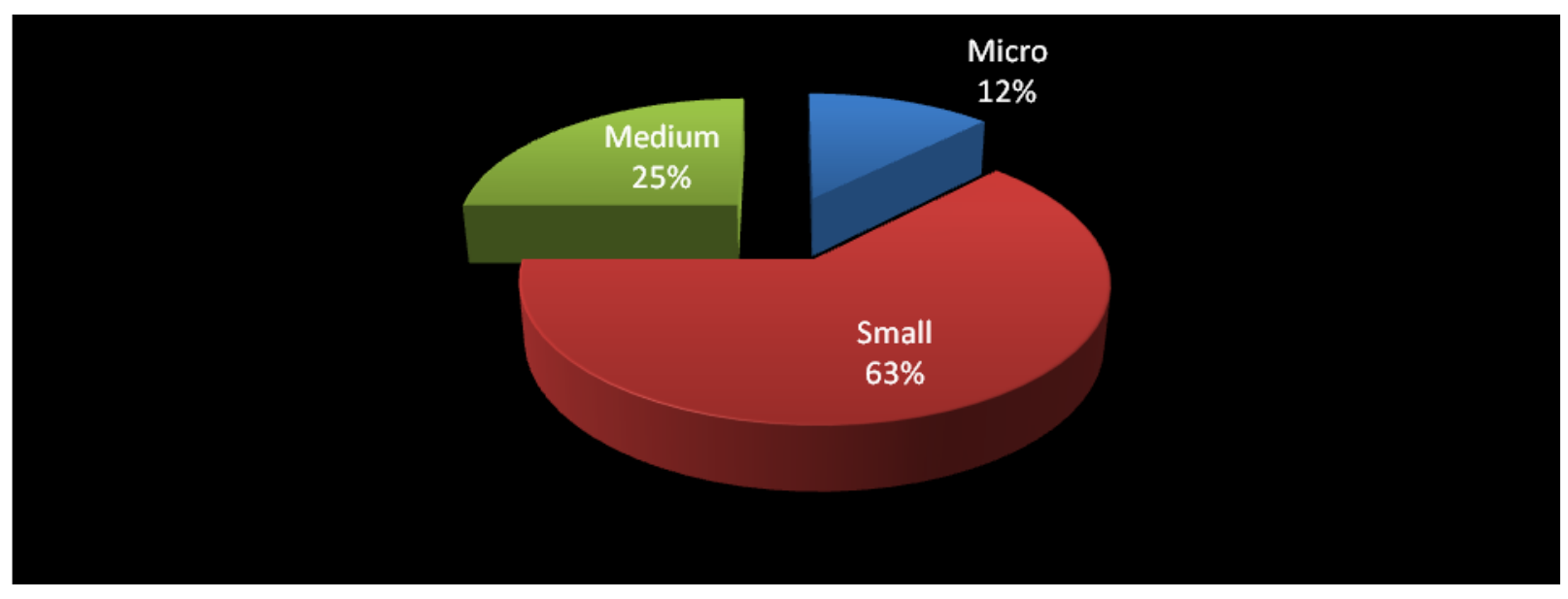

Figure 5: A breakdown of the Categories of Enterprises selected.

Source: Fieldwork 2017

Agro-allied enterprises had the greatest number of Micro, Small and Medium Enterprises. Others are catering service and portable water enterprises in the medium scale. A further breakdown of the MSMEs and their composition in each of the north-central states are presented in Table 1.

Table 1: State, Enterprise Type and Composition

\begin{tabular}{|c|c|c|c|c|}
\hline \multirow[t]{3}{*}{ State } & \multirow{2}{*}{\multicolumn{3}{|c|}{ Composition }} & \multirow{3}{*}{$\begin{array}{l}\text { Total Number } \\
\text { of Enterprises } \\
\text { in each state }\end{array}$} \\
\hline & & & & \\
\hline & Micro & Small & Medium & \\
\hline Kogi & - & 1(hair product manufacturing & 1 (farming/food production) & 2 \\
\hline Kwara & - & 1 (poultry farming) & 1(furniture manufacturing) & 2 \\
\hline Niger & - & 1(groundnut oil production) & - & 1 \\
\hline
\end{tabular}




\begin{tabular}{|c|c|c|c|c|}
\hline Abuja & $\begin{array}{l}1 \text { (feed } \\
\text { production) }\end{array}$ & $\begin{array}{l}\text { 2(garment wear/fashion } \\
\text { accessories and footwear) }\end{array}$ & 1(catering \& outdoor services) & 4 \\
\hline Nasarawa & - & $\begin{array}{l}\text { 4(bakery, garment, digital } \\
\text { photography) }\end{array}$ & - & 4 \\
\hline Jos & $\begin{array}{l}\text { 1(bee } \\
\text { farming/honey } \\
\text { production) }\end{array}$ & $\begin{array}{l}\text { 1(software } \\
\text { developer/computer services) }\end{array}$ & - & 2 \\
\hline Benue & - & - & 1 (portable water production) & 1 \\
\hline Total & 2 & 10 & 4 & $\Sigma=16$ \\
\hline
\end{tabular}

Source: Fieldwork 2017

Table 2: Performance Indicators of Supply Chain Management in MSMEs

\begin{tabular}{|c|c|c|c|c|c|c|c|}
\hline Key Performance & Response & & & & & Average & Ranking \\
\hline $\begin{array}{l}\text { Indicators (KPIs) } \\
\text { of Supply Chain }\end{array}$ & $\begin{array}{l}\text { Very } \\
\text { Unsatisfied }\end{array}$ & Unsatisfied & $\begin{array}{l}\text { Neither } \\
\text { Satisfied nor } \\
\text { Unsatisfied }\end{array}$ & Satisfied & $\begin{array}{l}\text { Very } \\
\text { Satisfied }\end{array}$ & $\begin{array}{l}\text { Weighted } \\
\text { Score }\end{array}$ & $\begin{array}{l}\text { Based on } \\
\text { Score }\end{array}$ \\
\hline
\end{tabular}

$\begin{array}{lllll}\text { Assigned } & \text { Assigned } & \text { Assigned } & \text { Assigned } & \text { Assigned } \\ \text { Weight } & \text { Weight } & \text { Weight } & \text { Weight } & \text { Weight }\end{array}$

$\begin{array}{lllll}\text { (1) } & \text { (2) } & \text { (3) } & \text { (4) } & \text { (5) }\end{array}$

$\begin{array}{llllllll}\text { Total Delivered } & 4(25 \%) & 5(31.25 \%) & 4(25 \%) & 3(18.75 \%) & 0(0 \%) & 1.625 & 7^{\text {th }}\end{array}$

Cost: One of the ways to support total delivered cost measurements are with a complementary metric on total cycle time, which measures the total amount of time it takes for a product to pass through the supply chain.

\begin{tabular}{llllllll}
\hline Customer & $2(12.5 \%)$ & $4(25 \%)$ & $7(43.75 \%)$ & $3(18.75 \%)$ & $0(0 \%)$ & 2.688 & $1^{\text {st }}$ \\
Service: The & & & & & & \\
favored approach & & & & & & \\
to measuring & & & & & \\
customer service & & & & \\
in its broadest & & & & \\
sense is with &
\end{tabular}


metrics for

on-time full

deliveries or line

item fill rate,

which are the most

meaningful

aspects of

customer service.

$\begin{array}{llllllll}\text { Supply } & 4(25 \%) & 5(31.25 \%) & 4(25 \%) & 3(18.75 \%) & 0(0 \%) & 2.375 & 3^{\text {rd }}\end{array}$

Variability:

Supply variability

KPI's measure the

status of Inventory

against

conformance to

lead times and

promise dates.

Included are

metrics for

performance to the

production plan,

schedule

attainment, asset

utilization,

capacity

utilization, vendor

deliveries, and

item availability at

all stocking

locations

(including the

customer's

location).

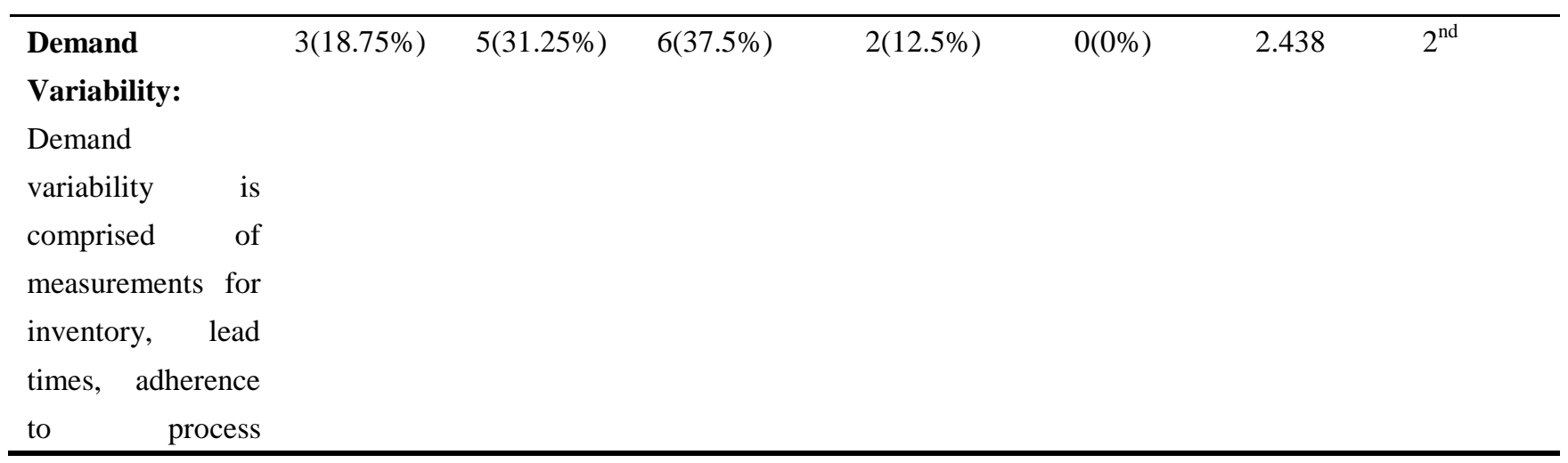


capability,

improvement to

process capability,

conformance to

plan, actual

demand versus

forecast demand,

forecast accuracy,

and forecast error.

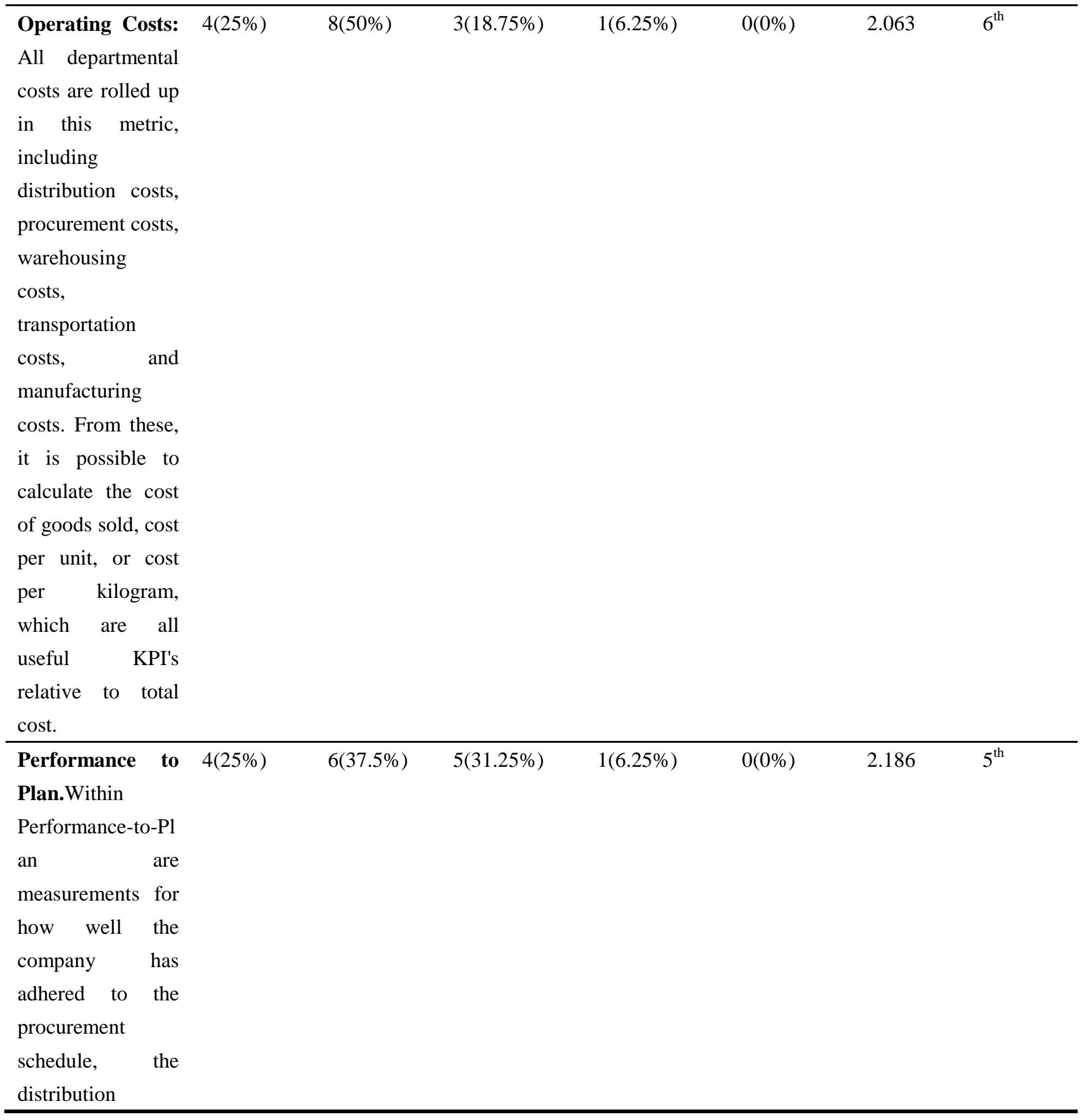




\begin{tabular}{|c|c|c|c|c|c|c|c|}
\hline $\begin{array}{l}\text { schedule, the } \\
\text { warehousing } \\
\text { schedule, the } \\
\text { transportation } \\
\text { schedule, and the } \\
\text { manufacturing } \\
\text { schedule. }\end{array}$ & & & & & & & \\
\hline $\begin{array}{l}\text { Inventory: } \\
\text { Metrics which } \\
\text { support the } \\
\text { Inventory KPI are } \\
\text { in the areas of total } \\
\text { inventory, } \\
\text { inventory turns, } \\
\text { record accuracy, } \\
\text { obsolete } \\
\text { inventory, } \\
\text { working } \\
\text { inventory, } \\
\text { non-working } \\
\text { inventory (along } \\
\text { with working } \\
\text { inventory, this } \\
\text { measures the } \\
\text { quality of your } \\
\text { inventory), and } \\
\text { item availability }\end{array}$ & $3(18.75 \%)$ & $6(37.5 \%)$ & $6(37.5 \%)$ & $1(6.25 \%)$ & $0(0 \%)$ & 2.313 & $4^{\text {th }}$ \\
\hline
\end{tabular}

Note: Weighted average score was derived from the Likert scale as follows: (Number of respondents * Weighting for column 1$)+($ Number of respondents * Weighting for column 2$)+($ Number of respondents * Weighting for Column 3$)+($ Number of respondents $*$ Weighting for column 4$)+($ Number of respondents $*$ Weighting for column 5) / Total number of respondents.

Table 2 shows that none of the MSMEs exhibited very satisfactory performance given the selected key performance indicators of the supply chain. Overall, we can see that, of the seven key performance indicators employed, Customer Service rated most highly, with an average weighted score of 2.688 on a 5 point scale assessment. This means that the MSMEs showed some level of performance on this issue.

Across various industries, there is awareness that pricing and commercial terms should better reflect the fact that some customers cost more to serve than others. To address these challenges, companies are increasingly focused on managing total delivered cost (TDC) (SupplyChainBrain, 2013).A critical look at Table 2 shows that in general, MSMEs reported the lowest performance satisfaction on Total Delivered Cost indicator of their supply chain. A breakdown of the report shows that $31.25 \%$ of MSMEs were unsatisfied with their performance and $25 \%$ of 
MSMEs were very unsatisfied. On the other hand, $18.75 \%$ of MSMEs felt satisfied. Nonetheless, $25 \%$ of MSMEs were undecided about this issue.

On the issue of Supply Variability, about $31.25 \%$ of the MSMEs were unsatisfied with their performance as indicated in Table 2, more so, 25\% were very unsatisfied. However, $18.75 \%$ of MSMEs were of the opinion that their performance was satisfactory. As earlier reported, none of the MSMEs showed very satisfactory performance.Concerning Demand Variability, $12.5 \%$ of MSMEs were of the perception that their performance is satisfactory.On the contrary, a significant majority(31.25\%) of the MSMEs were unsatisfied and an additional percentage of MSMEs (18.75\%) were of the view that their performances were very unsatisfactory. Variability in all forms is the enemy of supply chain efficiency. If there was no variability in consumers' tastes, in product portfolios, in manufacturing, transportation, and distribution lead times, or in any of the other of the processes for buying materials, producing products and distributing them to consumers, then supply chains would run like clockwork with very little need for sophisticated management (JDA, n.d.). Obviously, that is not reality; in fact, variability increases every year as supply chain structures continuously morph in a competitive environment based on customer-centricity, responsiveness, and efficiency.

SMEs have the potential to contribute significantly to job creation, the production of goods and the provision of services. However, most of the 17 million of the SMEs in Nigeria, have largely been ignored and their impact is hardly felt(AGPartnerships, 2014). One reason for this is the high cost of operating businesses in the country, especially, the financial cost. This includes high operating costs from a dependence on generators and alternative water supply, difficult transportation access and considerably high accommodation prices. The financial cost burden also encompasses the near absence of affordable credit to genuine businesses and the unwillingness of financial institutions to provide venture capital to start-up firms. In Table 2, the Operating Costs performance indicator reveals that 50\% of the MSME performed unsatisfactorily and the views from 25\% MSMEs further shows very unsatisfactory as against $6.25 \%$ of MSMEs that expressed satisfactory performance. Nonetheless, the implications of such high costs of doing business are far-reaching. Enterprises find their growth from small to medium or medium to large, very difficult without government intervention. These costs limit the potential longevity of businesses as changing trends make innovation key and high operating costs reduce the firm's ability to keep pace with innovation.

Any business, even if it is deemed to be well managed, is capable of improving its performance. Similarly, a business may find that it is underperforming, which could eventually threaten its survival (Guichet (2015).As depicted by the data on Table 2, the Performance to Plan shows $6.25 \%$ of the MSMEs reporting a satisfactory performance, however, a large portion of the MSMEs were dissatisfied: $37.5 \%$ unsatisfied; and $25 \%$ very unsatisfied.

About the issue of Inventory, $6.25 \%$ of the MSMEs were satisfied with the way they handle their inventories, nonetheless, a large percentage of MSMEs was not pleased by the way they have been handling their inventories. Some were unsatisfied (37.5\%) while some were very unsatisfied (18.75\%). It should be noted that inventory control or management is an on-going challenge that businesses have to address all the time. It cannot be solved once and for all, but require persistent work and innovative approaches, else they can become serious problems that have a major impact on the profitability of a business (dashboard stream, n.d.).

Generally, ranking the totality of the MSMEs in terms of least performance given the key indicators on Table 2, the data shows that the MSMEs performed least on Total Delivered Cost indicator followed by Operating Costs indicator, Performance to Plan indicator, Inventory indicator, Supply Variability indicator, Demand Variability, and Customer Service. 


\section{Conclusion and Recommendation}

Today's business environment for MSMEs as well as large, global companies is more fluid and complex than ever before. Companies are adapting their supply chains to respond to increasingly competitive market conditions and to deliver higher revenue and greater value to their shareholders and customers. Leading companies view the supply chain as a competitive differentiator on the corporate strategic agenda. The concept of the supply chain itself has undergone a radical revolution in recent years. It is no longer a simple matter of "logistics" or "product delivery," as large, global companies now recognizes that agile, optimized supply chains drive improved corporate customer service, higher margins and increased revenue growth (Ernst and Young, n.d.).In order to succeed, MSMEs in Nigeria, particularly in the north-central states need to be able to increase inventory velocity, achieve the shortest possible cycle times, continually improve their supplier performance and drive their sales and market share. Supply chain management is central to this (Staff Writer, 2017).

\section{Research Limitations/Implications}

Using indicators for the measurement of SCM performance creates an understanding of the supply chain processes, guides collaboration efforts and optimises supply chain excellence (Fawcett et al., 2007). According toGunasekaran and Kobu (2007), "No measures, no improvement,', and it is essential to measure the right things at the right time in a supply chain so that timely action can be taken.

Due to unavailability of secondary data, structured questionnaire was employed to collect responses of the respondents. Converting the responses to a Likert-type question into an average seems an obvious and intuitive step, but it does not necessarily constitute good methodology (Decker, 2017). One important point is that respondents are often reluctant to express a strong opinion and may distort the results by gravitating to the neutral midpoint response. The sample size that was used was very small, a generalization of the results should be done with care and further research with a large sample and better methodology is encouraged. This study focused on MSMEs in North central states of Nigeria, further research is also recommended in other regions of Nigeria.

\section{References}

AGPartnerships

(2014).The

Cost

of

Doing

Business

in

Nigeria.https://www.agpartnerships.com/single-post/2014/09/28/The-Cost-of-Doing-Business-in-Niger ia.

Agusto and Co.(n.d.). Micro, Small and Medium Enterprises(MSMEs) Industry Report. http://www.agustoresearch.com/2016-Micro-Small-Medium-Enterprises.

Ajibefun, A. I., and Daramola, A. G. (2003), Efficiency of Microenterprises in the Nigerian Economy. African Economic Research Consortium, Research Paper134.

Alvarez, R., and Crespi,G. (2001, 2003).Determinants of Technical Efficiency in Small Firms.Small Business Economics, 20(3), 233-244.

Chow, W. S., Madu, C. N, Kuei, C-H., Lu, M.H., Lin, C., and Tseng.H. (2008).Supply Chain Management in the US and Taiwan: An Empirical Study. The International Journal of Management Science, 36(1), 665- 679 .

Chowa, W. S., Madu, C. N., Kuei, C.-H., Lu, M. H., Chinho, L., and Tseng, H.(2008). Supply Chain Management in the US and Taiwan: An Empirical Study. The International Journal of Management Science, 36 (5), 665-679.

Christopher, M. L. (1992) Logistics and Supply Chain Management. London: Pitman Publishing.

Connect Nigeria(n.d.). The Nigerian Economy: The Role of SMEs. http://www.connectnigeria.com/articles/2015/08/the-nigerian-economy-the-role-of-smes/. 
Council of Supply Chain Management Professionals.(2010) Supply Chain Management Terms and $\begin{array}{llll}\text { Glossary.Retrieved } \quad \text { August } & 2013, & \text { from }\end{array}$ http://cscmp.org/sites/default/files/user_uploads/resources/downloads/glossary.pdf.

Coyle, J. J., Langley, C. J., Novack, R. A., and Gibson, B. J. (2013).Supply Chain Management: A Logistics Perspective. Mason, $\mathrm{OH}$ : South-Western Cengage Learning.

CSCMP, C., Haozhe, C., Clifford, D.C., Brian, J. G., Joe, B. H. (2014). Supply Chain Concepts.http://www.informit.com/articles/article.aspx?p=2166717\&seqNum=2.

Dashboard stream (n.d.). Top $10 \quad$ Challenges of Business Inventory Management.http://dashboardstream.com/top-10-challenges-of-business-inventory-management/.

Decker, F. (2017).How to Average Likert Scales. https://sciencing.com/average-Likert-scales-6181662.html. $\begin{array}{llllll}\text { eRepublik Wiki } & \text { (n.d.).The Sorth } & \text { Central } & \text { States. }\end{array}$ https://wiki.erepublik.com/index.php/North_Central_States.

Ernst and Young (n.d.).Driving improved supply chain results: Adapting to a changing global marketplace.www.ey.com/Publication/...supply.../Driving_improved_supply_chain_results.pdf.

Fawcett, S. E., Ellram, L. M., and Ogden, J. A. (2007).Supply Chain Management: From Vision to Implementation. Upper Saddle River, NJ: Prentice Hall.

Fynes, B., Voss, C., and de Búrca, S., 2005.The Impact of Supply Chain Relationship Dynamics on Manufacturing Performance.International Journal of Operations and Productions Management, 25(1), 6-19.

Ganesan, S., (1994) Determinants of Long-term Orientation in Buyer-Seller Relationships.Journal of Marketing, 58 (1),50-69.

Guichet (2015).Identifying and preventing underperformance.http://www.guichet.public.lu/enterprises/en/sauvegarde-cessation-activite/sauvegard e-activite/detection-prevention/sous-performance/index.html.

Gulati, R. (1995). Does Familiarity Breed Trust? The Implications of Repeated Ties for Contractual Choice Alliances.Academy of Management Journal, 38 (1),85-112.

Gunasekaran, A., and Kobu, B. (2007). Performance Measures and Metrics in Logistics and Supply Chain Management: A Review of Recent Literature (1995-2004) for Research and Applications. InternationalJournal of Production Research, 45(12), 2819-2840.

JDA

$$
\text { (n.d.).Managing Demand Variability }
$$

and

Volatility.https://blog.jda.com/managing-demand-variability-jda-software-supply-chain/.

Kale, Y. (2015).Micro, Small and Medium Enterprise National Survey 2013.www.nigerianstat.gov.ng/pdfuploads/MSME\%20Presentation.pdf

Ketchen, D. J. Jr., Rebarick, W., Hult, G. T. M., and Meyer, D. (2008). Best Value Supply Chains: A Key Competitive Weapon for the $21^{\text {st }}$ Century. Business Horizons, 51, 235- 243.

Klein, R. (2007). Customization and Real-Time Information Access in Integrated business Supply Chain Relationships.Journal of Operations Management, 25(1),1366-1381.

Lee, V., and Harvie, C. (2010). How Do Vietnamese's SMEs Perform: Technical Efficiency in the Manufacturing Sector and Its Sub-sectors, School of Economics, Faculty of Commerce, University of Wollongong, Australia.

Llerena, D., Duvallet, J., Lemarié, S., and Penz, B. (2006). Evaluer Les Impacts Du PartageD'information: Objectif, Méthodologie, Résultats.www.copilotes.eu.

Maps of World (n.d.).Location of Nigeria.https://www.mapsofworld.com/nigeria/nigeria-location-map.html. 
Meeken, Z. (2013). 5 Ways to Increase Supply Chain Performance.http://www.business.org/software/supplier/ways-to-increase-supply-chain-performance/
MydNigeria
(n.d.).
North
Central
Region
Guide.

http://www.mydnigeria.com/nigeria-travel-infomation/nigeria-regional-information/north-central-niger ia-region-guide/.

Onugu, B. A.N.(2005). Small and Medium Enterprises (SMEs) in Nigeria: Problems and Prospects.http://stclements.edu/grad/gradonug.pdf.

Oyelaran-Oyeyinka, B.(n.d.). FSS 2020 International conferences: Issues, Challenges, and Prospects.https://www.cbn.gov.ng/fss/wed/SME_Issues, \%20Challenges\%20and\%20Prospects_Oy eyinka\%20Banji.pdf

Quayle, M. (2003).A study of Supply Chain Management Practices in UK Industrial SMEs.Supply Chain Management - An International Journal, Vol. 8 No. 1, pp. 79-86.

Staff Writer (2017).Supply chain management: How SMEs can succeed in Africa.https://www.howwemadeitinafrica.com/supply-chain-management-smes-can-succeed-africa/.

SupplyChainBrain (2013).Getting a Handle on Your Total Delivered Cost.http://www.supplychainbrain.com/content/latest-content/single-article/article/getting-a-handle-onyour-total-delivered-cost/.

Trung, H., and Belihu, M. (2010). Increasing the Performance of SMEs in Supply Chains of Large Enterprises: A SME Perspective.Master's Thesis in Logistics and Innovation Management.Faculty of Engineering and Sustainable Development.https://www.diva-portal.org/smash/get/diva2:361038/FULLTEXT01.pdf Wikipedia (n.d.).State Nigeria.https://en.wikipedia.org/wiki/States_of_Nigeria.

World Atlas (n.d.).Where is Nigeria? http://www.worldatlas.com/af/ng/where-is-nigeria.html.

\section{Copyrights}

Copyright for this article is retained by the author(s), with first publication rights granted to the journal.

This is an open-access article distributed under the terms and conditions of the Creative Commons Attribution license (http://creativecommons.org/licenses/by/4.0/). 